\title{
Are aids enough to empower: case of peatland Liberica Coffee farmer in Indonesia
}

\author{
Made Deviani Duaja ${ }^{1}$; Elis Kartika² Johannes $^{3^{*}}$ \\ 1), 2) Faculty of Agricultural, Universitas Jambi, Indonesia \\ ${ }^{3)}$ Faculty of Economics and Business, Universitas Jambi, Indonesia \\ *To whom correspondence should be addressed.Email: johannes@unja.ac.id

\begin{tabular}{|l|l|l|l|l|}
\hline DOI: & Received: & Revised: & Accepted: & Published: \\
10.22437/ppd.v8i4.10831 & 25.09 .2020 & 03.11 .2020 & 04.11 .2020 & 07.11 .2020 \\
\hline
\end{tabular}

\begin{abstract}
Many agents have been involved to empower peatland farmers who cultivate Liberica Cofee. They have the same general purposes to save farming practices, but they have different programs and activities. Many agents involved had worried to blur focus and targets. Hence, the purpose of this study is to reveal empowering practice and performance. The study is located in Mekar Jaya village, the center of peatland Liberica Coffee, and used a qualitative method where field notes, observation, and in-depth interviews were used. Data collection was conducted in conjunction with the empowerment activities carried out by the research team in 2017-2019. The results showed the importance of empowering focus, coordination between groups, real participation of all groups and its members, and the need for local government intervention. Neglecting those will diminish the peatland farming environment function and farming roles to the farmer. In the future, the practice of empowerment will be more complex due to the global demands on the sustainability of peatlands increase. Hence, empowering could be started from farming improving, increasing productivity, and followed by increasing farmer's and group's capacity to manage both on economics and environmental value of peatland farming.
\end{abstract}

Keywords: Areca nut, BUMDES, Farmer groups

JEL Classification: Q12, Q14, Q18

\section{Introduction}

Liberica Coffee is a local indigenous commodity that belongs to West Tanjung Jabung Regency, Jambi Province, Indonesia. Based on the three-year sub-district report it was found that the area of coffee plantations is around 400 ha (BPS Kabupaten Tanjung Jabung Barat, 2019). As an indigenous commodity, the Minister of Agriculture of the Republic of Indonesia issued decree No. 4968 / SR.120 / 12/2013 which determine that Liberica Coffee obtained the MPIG certificate (Society for the Protection of Geographical Indications). This appreciation is commonly established to encourage the local government to develop the indigenous community as the broad-based for local economic consideration.

Legal recognition caused various institutions involved to empower program with various activities and different reasoning. In doing so, this commodity is expected to contribute greater to the surrounding farmers.

The reasons for local government, provincial, and regional to enlarge and develop that coffee mainly is based on local politics and economic policy (Esparcia, \& Serrano, 
2015). So, that coffee is even intended to be the basis of export commodities. Furthermore, several firms and state-owned corporations surrounding involved in a kind of CSR (Corporate Social Responsibility) and others for different reasons. Mainly, the corporation aims to brand itself for public purposes.

For academicians and other environmentalist institutions, the challenge of improving coffee plantation focuses on knowledge development. They examined everything related to the coffee; its origin, seed purity, low productivity, and its ability to survive in peatlands. In this connection, they found 9 types of coffee that are caused by cross-seeding between one seed and another in the plantation. They want farming in the peatlands to remain sustainable to keep the environment function.

Peatlands plantations are supported by unique water management that had been implemented by the local community for a long time. To enable watering two trenches large and small is build. The small trench connects the farm to a large one that connects to the rivers. The trench water level is affected by the tides, so as the tide rises the large trench delivers water to the plantation through a small trench. Conversely, when the tide is down, farmers will set up the water level by setting up the floodgates that have been installed to keep the water level afloat. Such practices will protect the irrigated peatlands, thus avoiding the threat of fire.

Farmers plant Liberica Coffee intercrops it with Areca Nut plants. They consider the two plants complement each other both socially and economically. Additionally, these two commodities can produce yield together where Areca Nut gives a different taste to the coffee, which made coffee has a unique taste. Areca Nut functions as a coffee shading plant. However, the coffee researchers are not recommended Areca Nut but Lamtoro (Leucaena). It belongs to tropical trees where it functions as a shade crop as well as a soil fertilizer that is needed naturally by the plantations.

University of Jambi's research team in 2015 reported that the productivity of peatland coffee is very low, it was 400 kilograms per year. This is only one-tenth of the maximum yield of good quality that reaches 4 tons yield per year. It is caused by unsecured seed, pest and disease attacks, and the dry season.

The dried season occurs once in two years which causing fires and damage plantation on peatlands. The fire damaged the plantation prevent good yield. Based on the observation, it is proofed that good gardens avoid fire, while the poor will repeatedly burn in the dry season. Therefore, it is argued that to reduce fires occurrence is to maintain farmer plantation for they protect the plantation themself.

Farmers in Mekar Jaya are mostly local independent immigrants who still uphold a sense of kinship and continue their home activities. They started farming together with the government's efforts to prepare peatland for new settlements. The construction of the main trenches and worms is the requirement for farming and settlement. Land clearing at the beginning of settlement and farming has collaborated with local government programs especially to prepare large trenches and worm trenches.

Residents are self-employed who came from the East Java, the others are Bugis and Banjar tribes who were known as experts in managing peatlands for agricultural activities. Mekarjaya is quite prominent in terms of cultivating coffee and Areca Nut plants, several people have obtained certificates as seed producers. Furthermore, in the village, some residents have produced Luwak coffee which is known as export coffee. To keep sustain peatland plantation mainly is depending on the commodities selection. Accordingly, Nazemi, et al. (2012) reported that the selection of local plants that varied from one location to another is the key to the sustainability of plantations on peatlands.

Peatland researchers so far have focused more on technical cultivation issues, how to maintain their environmental functions. Widiawaty (2011) reminded the importance of water governance, Agus \& Tinning 2008 argued that mistakes in water management would lose the function of peat to maintain global warming. Researchers who revealed 
the behavior of farmers such as Firmansyah, et al. (2017) Noor, et al. (2014) emphasized the need for a harmonious relationship between researchers and farmers.

In contrast, studies on farmers empowering in terms of aid practices are still rarely conducted, even though it is important to reveal that the success of the empowering program is mainly determined by beneficiaries' behavior. Accordingly, this study is intended to provide a broad perspective of empowering farmers on peatlands which contributes to the consideration of stakeholders to develop Liberica coffee in peatland.

\section{METHODS}

As the nature of qualitative research, the motivation is to reveal problems that still require scientific exploration with various scientific sides (Yin, 2011). Sarah \& Alan (2009) mention the reason is to guide the direction of the next scientific approach. Accordingly, the method used includes participatory approaches, observations, and indepth interviews with various sources: group leaders, farmers, traders, and involved stakeholders (Knox \& Burkard, 2009).

Several subjects used as sources of information consider the fulfillment of information that has been collected (Marshall, \& Fontenot, 2013). This is confirmed that the strength of qualitative research is to reveal an in-depth understanding of an event without having to do a hypothesis test. So research tools are 1) participatory, 2) FGD, and 3 ) observation. Sampling in qualitative research is determined purposively in which researchers independently determine the informants (Anderson, 2010; Robinson, 2013).

\section{RESULT AND DISCUSSION}

\section{General description}

Liberica plantation is found in the Betara sub-district, Province of Jambi, Indonesia. Betara consists of 12 villages where the larger plantation is found in three respectively villages: Mekar Jaya (400 ha), Bunga Tanjung (353 ha), and Muntialo (260 ha). Each plantation area was organized by a farmer group that has a function as a farmers' forum to arrange their annual program. The research location is shown in Figure 1. Each group is administratively accompanied by a field officer (PPL) to direct the planning of farming every year. A group is a requirement for receiving any aids that deliver by the government and other agencies. Groups prepare rules to their member including to any aids received such as machines and post-harvest equipment, how to use them on a rolling basis and cost to be paid.

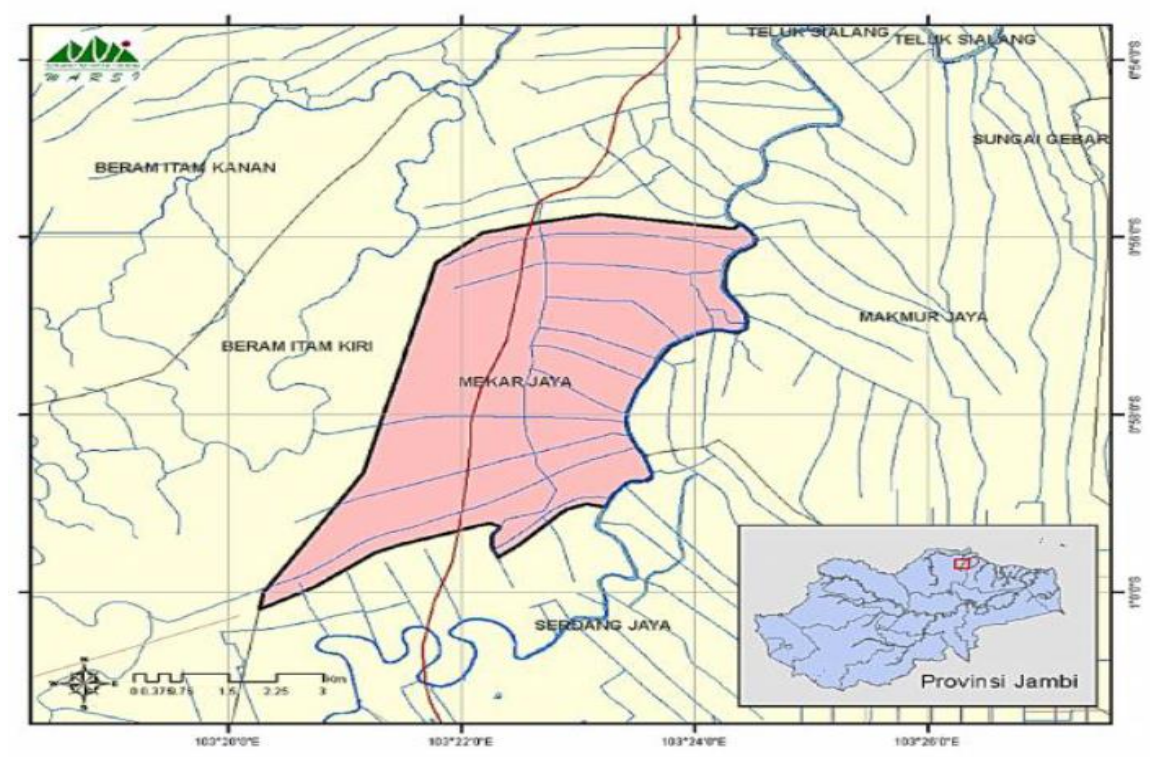

Figure 1. The site of Mekar Jaya Village 
. According to the peatland expert, Mekar Jaya village consists entirely of peat where its depth reaches 1.4 meters. Such conditions require special competence so farming practices do not damage and functions and keep maintained the plants. In general, fibrous-rooted plants can grow on peatlands. Hence, farmers perceived coffee as a good choice for their plantation and they believed that Liberica only could grow in peat.

Environmentalists are aware of the risks that threaten peat farming mismanagement so that incentives are needed to empower the farmers. Accordingly, Wichmann, (2010) emphasized the global climate impact requirement so farmers require more appropriate incentives, not in the form of finance but a network where they can teach one another. Dzeco, et al. (2010) identified such incentives as a field school need where beneficiaries could teach each other for group action. Additionally, Bartlett (2008) mentioned the consideration is not based on technical criteria and site feasibility, but the importance of empowerment due to the local complex consideration

The quality of coffee plantation until 2019 gradually decreases due to the oil palm expansion by farmers themself and firms. Farmer perceived oil palm plantation is better than coffee because it provides a regular income and easy market. The plantation is worsened by the presence of private companies that plant oil palm by "destroying" peatlands. They also bought farmers' yield to make marketing practiced be easier compare to coffee marketing.

\section{Empowering Practices}

Black's review on empowering practices (2000) classified intervention to be 4 types: 1) top-down line of transfer of technology; 2) participatory "bottom-up" approaches, 3) one-to-one advice or information exchange, and 4) formal or structural education and training. Generally, it is recognized that the most appropriate approach is the participatory type that provides some advantages: 1) recognizing local ways, 2) support local innovation, 3) consistent with ethical principle, 4) providing an environment that allows complex landscape problems, 5) acknowledging farmers value sharing, 6) encourages producer ownership, 7) prepare process group.

Meanwhile, Padel (2001) argued the importance of empowering effectiveness, the role of innovator in every empowering process, especially in terms of technology. He added hence that innovators who belong to the group beneficiaries have a pattern function to the imitators who could learn success points from an innovator. However, he added that the outsider is not easy to follow because of its complex substance. In this case, one of the success points is participation that is not easy to be recognized. Iqbal, (2007) hence identified a quasi-participation where participants were only active at the initial of intervention when assistance was prepared. After that, the level of participation declined and paid less attention to the group goals establishing. At this point, Umesh et al. (2010) emphasized the three succeed empowering determination: (a) empowered the groups, (b) increased stakeholder interaction and involvement within the clusters, and (c) the group will be enabled to fulfill market requirements.

Based on in-depth interviews, regarding the aids, Mr. Supardi, one of the beneficiaries, emphasized the importance of aids. He said:

It's okay if I'm expelled from MPIG caused they don't provide me any aids. They demanded me to pay dues, but they gave nothing

MIPIG is a group that receives certificates from the government. They have the responsibility to maintain the supply and quality of the indigenous commodity. To support operational expenses, they charged members. Conflict emerges With Mr. Supardi due to his practice producing Luwak coffee employee Wild Mongoose to ferment cherry coffee. MIPIG in this case does not allow Moongoose in the coffee production process. 
Mr. Supardi is an advanced farmer, partnering with Bank Indonesia and Jambi University and he is an innovator who sells beans and he has regular buyers. It is a premium taste that is intended to be exported. According to Mr. Supardi, only institutions that provide aids should be followed.

In terms of empowering, the group has an important role. There are two dominant groups, Sidomuncul and Sriutomo which are located in a different village and they received different aid resources. Sido Muncul received a coffee shop building and other aids from Petrochina. Aids are intended to serve customers and promoting coffee. The two groups have conflict in terms of bean quality.

Mr. Edi focused on producing coffee powder. Otherwise, Mr. Badrin focused on produce different quality beans that enabling them to sell at different prices. In doing so, coffee should be processed in a good way. Processing should be started from harvest activities and brings yield to the doom for dying. Mr. Edi does not approve that practice does, he does not ensure yield differentiation will affect farmers income

Other conflicts were also found in the use of machinery and equipment among members of the beneficiary group. Members who are supposed to share equipment usage are not going well. The tendency is that the use of the means of production is used by the recipient, not by the members in turn.

In the function of the group, de Loë, et al., (2015) reported that the collaborative perspective of the group is needed especially in the situation more agents involved. He reminded the personal (actor) role who can communicate with everyone could be the succeded factor. In a broader perspective Demos (2011) noted the importance of social entrepreneurship who can direct group action that can benefit even group people.

The problem is also found in using machines-aid. Several machines failed to be used for these reasons: 1) the size of the machines (breaking machines, sorting) did not match the size of Liberica beans due to Liberica coffee was bigger than Arabica and Robusta coffee, and 2) automatic machine did not work due to lack of demonstration. This includes aids prepared by BRG (Badan Restorasi Gambu), Peat Restoration Agents that established by the Indonesia government to restore the function peatlands for global purposes. Some institutions and activities involved to empower farmers are shown in Table 1.

The results of the interview on their goals and activities in the empowerment activities are as follows.

1) Indonesian Bank (BI). BI empowering purpose is to strengthen the group to become MSME's, called LKMA (Agribusiness Microfinance Institutions). Simply said, BI wants the group to be bankable. Hence, BI delivers drying houses for coffee and Areca Nut and roasted machine. Until 2019, it does not use any more due to broken condition. It is worth mentioning LKMA guidance from BI that succeed to prepare LKMA Mekar Sejahtera in a different village in Betara Subdistrict. BI's perception of the aids progress was told by one of its staff as follows.

BI perceived that delivering assistance to farmers is more than enough. According to them, farmers' problems now are more about their motive and creativity in developing farming so they can provide better results

2) Provincial government. Jambi Provincial government's purpose is to promote indigenous local products, including Liberica coffee with others through promotional activities. Hence they involve groups participating in the trade exhibitions conducted both by the private sector and government agencies. It is hoped that the exhibition will create demand. But, when the demand for coffee is obtained, the group cannot fulfill because it does not get sufficient yields. 
3) Local Government. The local government's purpose is to increase the area of coffee plantations by providing fertilizer seeds, and others. However, efforts to expand coffee plantations were unsuccessful due to land constraints that were often inundated with water and the tendency of farmers to plant oil palm.

4) Corporations. One of the corporations involved is Petrochina. It used the CSR (Corporate Social Responsibility) program to provide machines, coffee bean grinders, and buildings to process coffee beans. In 2019, they built a coffee shop as a resting place for the traveler to promote coffee. Recently, they provide plantation as an environment-based tourist destination by preparing the bicycle route.

5) BRG. It is established in 2014 and the purpose is to restore peatlands function both technically and economically. Attention to peatlands is increasing especially after frequent fires on peatlands, that occurs at least once in two years. Peatland fires not only damage the ecosystem but also the image of the Indonesian globally. BRG's activities are briefly derived from their slogan namely: rewetting, revegetation, and revitalization of the socio-economic village in the related peatland region. In this connection, Mekarjaya receives drying houses, and automated machines to produce sachet coffee.

6) NGO. NGO empowering farmers and communities for environmental protection reasons by keep peatland in a good cultivated manner. Their activities include expanding coffee plantation to other peatlands area, East Tanjung Jabung regency.

7) The University of Jambi. Certain lecturers conduct research and community services together with students. They received government competitive funds to improve the plantation quality on a small scale so that productivity and income hope to increase. Their orientation is to empower farmers by requiring farmers to prepare the land as a partnership plot. Farmers are encouraged for the yield produced by the partnership owned by the partner farmers.

Table 1. Some involved institutions on empowering and their activities

\begin{tabular}{|c|c|c|c|}
\hline No. & Institution & Aids Type & Goals description \\
\hline 1 & Bank of Indonesia & $\begin{array}{l}\text { - Post-Harvest Improvement } \\
\text { - Drying house, coffee grinder } \\
\text { machine }\end{array}$ & $\begin{array}{l}\text { 1) To make the group bankable, } \\
\text { known as the Agribusiness } \\
\text { Microfinance Institution } \\
\text { 2) Improving farmers yield quality }\end{array}$ \\
\hline 2 & $\begin{array}{l}\text { Provincial } \\
\text { Government }\end{array}$ & $\begin{array}{l}\text { - Post-harvest machine } \\
\text { - Promotions }\end{array}$ & $\begin{array}{l}\text { 1) Introducing and promoting } \\
\text { products to market both } \\
\text { nationally and internationally } \\
\text { 2) Provide product exhibition }\end{array}$ \\
\hline 3 & $\begin{array}{l}\text { Local government, } \\
\text { West Tanjung Jabung }\end{array}$ & $\begin{array}{l}\text { - Seeds, } \\
\text { - Compost, } \\
\text { - Coffee crushing machine } \\
\end{array}$ & $\begin{array}{l}\text { 1) Increase the area and quality of } \\
\text { coffee plantations } \\
\text { 2) Group empowerment }\end{array}$ \\
\hline 4 & $\begin{array}{l}\text { Corporations, } \\
\text { Petrochina }\end{array}$ & $\begin{array}{l}\text { - Post-harvest machine } \\
\text { - Establishing coffee outlets } \\
\text { - A tracking road to several } \\
\text { farmers' plantation }\end{array}$ & $\begin{array}{l}\text { 1) Promoting coffee quality } \\
\text { 2) Market expansion }\end{array}$ \\
\hline 5 & $\begin{array}{l}\text { BRG (Peat } \\
\text { Restoration Agency) }\end{array}$ & $\begin{array}{l}\text { - Dried house } \\
\text { - Sorting machine } \\
\text { - Sachet machine }\end{array}$ & $\begin{array}{l}\text { 1) Peatland revitalization so its } \\
\text { function be sustainable } \\
\text { 2) Farmer Socioeconomic } \\
\text { revitalization }\end{array}$ \\
\hline 6 & $\begin{array}{l}\text { NGO (Non-govern- } \\
\text { mental Organization) }\end{array}$ & - Seed preparing & $\begin{array}{l}\text { 1) Farming Expansion to another } \\
\text { peatlands area }\end{array}$ \\
\hline 7 & University of Jambi & $\begin{array}{l}\text { - Post-harvest machine } \\
\text { - Seed improvement } \\
\text { - Organic fertilizer }\end{array}$ & $\begin{array}{l}\text { 1) Farm Revitalization } \\
\text { 2) Group capacity building }\end{array}$ \\
\hline
\end{tabular}


Based on Table 1 and in-depth interviews with parties involved, some important point is explained.

Empowerment is a process that is more human-oriented rather than technical assistance or providing equipment. In this connection, each party involved provides assistance, equipment, and technology with different capacities and objectives. It caused the purpose of empowerment blurred. Farmers as beneficiaries are positioned as parties that have been lost participatory chance. This is found in the case of the fault of the machine aids an automatic sachet coffee machine which is not appropriate with the Liberica Cofee requirements, the two machines are stored at the farmer houses. In this connection, Friis-Hansen, \& Duveskog (2012) emphasize that empowerment is the focus of the process between the agent and the beneficiaries. Those fault for example occurs due to the lack of beneficiaries chance to say what they need. Furthermore, Sumane, et al., (2017) in this case suggested a necessity of the knowledge process synthesizing between recipients and aid providers so they complement each other.

Lack of coordination is found due to different empowering agent backgrounds and competence. Accordingly, Rogers \& Singhal (2003) emphasized that activities of empowerment and communication are inseparable. Communication will encourage transformation to achieve goals, especially for small groups. Practically the institutions involved can communicate, but not coordinate. This refers to the limitation noted by Hall, et al. (1976) in Bouckaert, et al. (2010), the basic principle of coordination is communicating what is being done to other fields so that they consider it in the role of each institution.

One of the poor group coordination performance described below:

Mr. Badrin, head of the Sri Utomo, group suggested that each group produce different coffee bean quality. So, the farmer will serve different buyers according to the quality they want. He hoped that inter-group competition will not occur because farmers have their respective buyers. This is difficult to be practiced due to the lack of communication between farmer groups.

The empowering practice is not simple due to vague beneficiaries' participation. Iqbal, M., (2007) identified it as pseudo participation where the beneficiaries participate just in the presence of an agent in the group. It is caused by the motivation to get aids as soon as possible.

The role of the group to transform resources to achieve shared goals is important in the empowering process (Rogers \& Singhal, (2003). Iqbal (2007) confirmed emphasized the importance of groups participating in the farm planning process to achieve shared goals. Additionally, Attanandana, et al., (2007) emphasized the importance of the leadership's role to improve the quality of empowerment practices. With a different point of view, Umesh, et al., (2010) identified groups as a cluster where beneficiaries and agents can learn from each other. Hence, Aberra (2004) noted the problem of empowerment due to the small plantation scale, so the cluster approach is needed to enforce the empowerment process.

Furthermore, Touri, (2016) emphasized the importance of communication which enabling beneficiaries to internalize global problems. De Loë, et al. (2015) identified it as a collaborative approach, while Mudege, et al. (2015) indicated the importance of joint action between partners involved in empowerment, and Hassink, et al. (2010) required a combination or varied approach on empowering: such as formal versus informal, and individual versus group approaches.

The problem empowering in the future will increasingly complex due to global demands on the peatland sustainability principle. Hence, Surahman, et al. (2017) said that peatland management in Indonesia must consider its environmental function because it contains rich organic material where poor land management will eliminate the 
environmental function. It will be a big issue for several large companies to turn peatlands into oil palm plantations. Planting is done by digging and then collecting excavated land to be planted with oil palm. Such practices are not allowed for it seriously damage peatlands function.

The problem of the institutional form of beneficiary groups in the future will be potentially problematic due to the dynamics of business organizations in rural areas. Since 2014, the Indonesian government has introduced BUMDES (village-owned companies) as an economic institution in the message and has facilitated this institution to develop. In this connection, Groups in Mekarjaya has an opportunity to be institutionalized in the form of BUMDES, but it is difficult to decide due to the aids ownership.

The issue of empowerment, however, must consider environmental and economic interests, especially local economy communities. Farmers, however, do not fully understand this, their considerations are more economic than environmental.

In terms of climate considerations, Wichmann, (2010) reminded the importance of farmer's incentives, not in the form of money, but networks that allowed them to learn from each other. Rawlins, \& Morris (2010) identified the environmental benefit as the non-used value of peatland is more prevalent to be considered globally. Bullock, \& Collier, (2011) made an analogy of environmental function as public good where people globally could experience it.

\section{CONCLUSIONS AND RECOMMENDATIONS}

\section{Conclusions}

Farmer's empowerment in peatland will be more complex in the future, it is not caused by resource scarcity but due to the lack of coordination. If the agencies involved don't prioritize strengthening, every action seems to solve the problem. The local government in this case could direct them so that each different party can receive empowerment priorities. In the future, coordination is increasingly important because of the presence of BUMDES as a local business institution that facilitates by the Government in the villages. It is hoped that farmer groups can be integrated with BUMDES, however, this is difficult to happen because of different understandings and interests. Until 2019, farmers could process coffee yields for they have received various aids and trained through different institutions. However, due to low coffee yields, production equipment, and machinery cannot function optimally and large and demand could not be fulfilled.

\section{Recommendations}

The empowering focus should start from the downstream sector, improving plantations that affect productivity increasing. Attention to peat will continue to increase due to global awareness to improve the quality of plantations on one side, but it must be accompanied by controls to limit the expansion of oil palm plantations on peatlands. For this reason, a form of strengthening is needed through empowering farmers and their groups.

\section{ACKNOWLEDGMENT.}

We would like to thank the Director-General of Higher Education in Jakarta for providing funding for three years, LPPM University of Jambi, and Warsi for preparing site research locations.

\section{REFERENCE}

Aberra, Y. (2004). Problems of the solution: intervention into small-scale irrigation for drought-proofing in the Mekele Plateau of northern Ethiopia. The Geographical Journal, 170(3), 226-237. doi:10.1111/j.0016-7398.2004.00122.x 
.Agus, F., \& Tinning G. (Eds.). (2008). Proceedings International Workshop on Posttsunami Soil Management, 1-2 July 2008. Cisarua, Bogor, Indonesia. Indonesian Agency for Agricultural Research and Development, Jakarta, Indonesia and New South Wales Department of Primary Industries, Wallongbar, NSW, Australia.

Anderson, C. (2010). Presenting and Evaluating Qualitative Research. American Journal of Pharmaceutical Education, 74(8), 141. doi:10.5688/aj7408141

Attanandana, T., Yost, R., \& Verapattananirund, P. (2007). Empowering Farmer Leaders to Acquire and Practice Site-Specific Nutrient Management Technology. Journal of Sustainable Agriculture, 30(1), 87-104. doi:10.1300/j064v30n01_08

Bartlett, A. (2008). No more adoption rates! Looking for empowerment in agricultural development programs. Development in Practice, 18(4-5), 524-538. doi:10.1080/09614520802181269

Bouckaert, G., Peters, G., \& Verhoest, K (2010). The coordination of Public Sector Organizations, Shifting Patterns of Public Management. United Kingdom: Palgrave Macmillan

BPS Kabupaten Tanjung Jabung Barat. (2019). Kecamatan Betara Dalam Angka. BPS Kabupaten Tanjung Jabung Barat.

Bullock, C. H., \& Collier, M. (2011). When the public good conflicts with an apparent preference for unsustainable behavior. Ecological Economics, 70(5), 971-977.

de Loë, R. C., Murray, D., \& Simpson, H. C. (2015). Farmer perspectives on collaborative approaches to governance for water. Journal of Rural Studies, 42, 191-205. doi:10.1016/j.jrurstud.2015.10.005

Demos, (2001). The rise of social entrepreneurs. Great Britain: BDW Associates

Dzeco, C., Amilai, C. \& Cristóväo, A. (2010). Farm field schools and farmer's empowerment in Mozambique: A Pilot Study, 9th European IFSA Symposium, 4-7 July 2010, Vienna (Austria)

Esparcia, J., Escribano, J., \& Serrano, J. J. (2015). From development to power relations and territorial governance: Increasing the leadership role of leader Local Action Groups in Spain. Journal of Rural Studies, 42, 29-42. doi: 10.1016/j.jrurstud.2015.09.005

Firmansyah, H., Yulianti, M., \& Alif, M. (2017). Strategi Komunikasi Dalam Penguatan Kapasitas Kelembagaan Pada Pengelolaan Lahan Gambut Melalui Peningkatan Sumberdaya Manusia di Sektor Pertanian Kalimantan Selatan. Metacommunication: Journal Of Communication Studies, 2(1), 119 -131

Friis-Hansen, E., \& Duveskog, D. (2012). The Empowerment Route to Well-being: An Analysis of Farmer Field Schools in East Africa. World Development, 40(2), 414427.

Hassink, J., Elings, M., Zweekhorst, M., van den Nieuwenhuizen, N., \& Smit, A. (2010). Care farms in the Netherlands: Attractive empowerment-oriented and strengthsbased practices in the community, Health \& Place, 423-430, https://doi.org/10.1016/j.healthplace.2009.10.016

Iqbal, M., (2007) Concept and Implementation of Participation and Empowerment: Reflection From The Coffee IPM-SECP, Makara, Sosial Humaniora, 11(2),58-70

Knox, S., \& Burkard, A. W. (2009). Qualitative research interviews. Psychotherapy Research, 19(4-5), 566-575. doi:10.1080/10503300802702105

Marshall, B., Cardon, P., Poddar, A., \& Fontenot, R. (2013). Does Sample Size Matter in Qualitative Research? A Review of Qualitative Interviews in is Research. Journal of Computer Information Systems, 54(1), 11-22. doi:10.1080/08874417.2013.11645667

Mudege, N. N., Nyekanyeka, T., Kapalasa, E., Chevo, T., \& Demo, P. (2015). Understanding collective action and women's empowerment in potato farmer 
groups in Ntcheu and Dedza in Malawi. Journal of Rural Studies, 42, 91-101. doi:10.1016/j.jrurstud.2015.09.002

Rawlins, A., \& Morris, J. (2010). Social and economic aspects of peatland management in Northern Europe, with particular reference to the English case. Geoderma, 154(3-4), 242-251.

Robinson, O. C. (2013). Sampling in Interview-Based Qualitative Research: A Theoretical and Practical Guide. Qualitative Research in Psychology, 11(1), 25-41. doi:10.1080/14780887.2013.801543

Roger, E.M. \& Singhal, A. (2003). Empowerment and Communication: Lessons Learned from Organizing for Social Change, Annals of the International Communication, Association, 27:1, 67-85, DOI: 10.1080/23808985.2003.11679022

Šūmane, S., Kunda, I., Knickel, K., Strauss, A., Tisenkopfs, T., Rios, I. des I., Rivera, M., Chebach, T., \& Ashkenazy, A. (2018). Local and farmers' knowledge matters! How integrating informal and formal knowledge enhances sustainable and resilient agriculture. Journal of Rural Studies, 59, 232-241. https://doi.org/10.1016/j.jrurstud.2017.01.020

Surahman, A., Soni, P., \& Shivakoti, G. P. (2017). Are peatland farming systems sustainable? Case study on assessing existing farming systems in the peatland of Central Kalimantan, Indonesia. Journal of Integrative Environmental Sciences, 15(1), 1-19. doi:10.1080/1943815x.2017.1412326

Touri, M. (2016). Development communication in alternative food networks: empowering Indian farmers through global market relations. The Journal of International Communication, 22(2), 209-228. doi:10.1080/13216597.2016.1175366

Yin, Robert, K., (2011). Qualitative research from start to finish. New York: The Guilford Press.

Wichmann, S., (2010). Economic incentives for climate-smart agriculture on peatlands in the EU, Report, Institute of Botany and Landscape Ecology, University of Greifswald

Widyaty, E., (2022). Kajian Optimasi Pengelolaan Lahan Gambut dan Isu Perubahan Iklim, Tekno Hutan Tanaman, Bo. 4 No. 2, 57-68

Umesh, N. R., Mohan, A. B. C., Ravibabu, G., Padiyar, P. A., Phillips, M. J., Mohan, C. V., \& Bhat, B. V. (2010). Shrimp farmers in India: Empowering small-scale farmers through a cluster-based approach. In In: De Silva S.S., Davy F.B. (eds) Success Stories in Asian Aquaculture. Dordrect: Springer. https://doi.org/10.1007/978-90481-3087-0_3 